\title{
The Potential Analysis of Dairy Cattle Farm Development at Dairy Farmer Group in West Ungaran District, Semarang Region
}

\author{
Iven Patu Sirappa \\ Teaching staff of Animal Husbandry Study Program of the UNKRISWINA Sumba, Jln. W. \\ Soeprapto No. 35 Waingapu, East Sumba, East Nusa Tenggara- Indonesia \\ Sunarso \\ Lecturer of Faculty of Animal and Agriculture Sciences, Diponegoro University, Tembalang \\ Campus, Semarang 50274 - Indonesia \\ Marthen P. Sirappa (Corresponding Author) \\ Researchers at Assessment Institute for Agricultural Technology of West Sulawesi, Kompleks \\ Perkantoran Pemerintah Provinsi Sulawesi Barat, Jln Abd. Malik Pattana Endeng, Mamuju - \\ Indonesia. E-mail: mpsirappa@gmail.com
}

Received: Oct. 25, 2018

doi:10.5296/jas.v7i1.14520
Accepted: Feb. 18, 2019 Published: Mar. 18, 2019

URL: https://doi.org/10.5296/jas.v7i1.14520

\begin{abstract}
The objective of the study was to determine the potency of dairy cattle development, famers income, factors influencing the income of dairy farmers in the West Ungaran District. This study was conducted from February to April 2016. The determination of the sample villages was using purposive based Livestock Farmer Group (LFG) and the total population of dairy cattle. Further, respondents were determined by using census method for 47 people; those were 13 respondents of "Mardi Mulyo" LFG members, 7 respondents of "Sumber Hasil" LFG members, and 27 respondents of "Ngudi Makmur" LFG members. This study used regression, and SWOT analysis. The results of this study showed the multiple regression analysis showed that milk production significantly influences the income of dairy farmers. Farmers income in "Mardi Mulyo", "Sumber Hasil" and "Ngudi Makmur" group in a row during one month arrived at IDR 703,292/had, IDR 2.157.250/had and IDR 1,649,395/had, respectively. In addition, SWOT analysis showed a total score of internal and external scores of 3.61 and 2.73. Based on the results of business development analysis of dairy cattle in West Ungaran District, it could be concluded that the dairy farm in category IV, stability strategy and coordinate points are in quadrant IV.
\end{abstract}


Keywords: dairy cows, factors influencing earnings, SWOT analysis

\section{Introduction}

Public dairy farm business has a considerable potential to be developed considering the high demand for the production of milk. The increasing of milk products offers opportunities for smallholders to realize better livelihoods. Dairy farming is often considered as a promising option to improve household income and nutrition in developing countries (Francesconi et al. 2010; Headey et al. 2014). One boost farmer incomes through animal protein intake of nutrients that contain complete and indispensable man are milk, which the domestic milk production only meet one-third, while two-thirds have to be imported. The total demand for milk in 2006 was 2.1 million tons, of which the new supply reached about 489 thousand tons this led in 2011 imports of milk increased by 9.82\% from 2010 (Directorate General of Animal Husbandry 2006; Directorate General of Animal Husbandry and Health 2012).

According to Firman (2010), presently, the national milk production supply is about $25-30 \%$ and the remaining of $70 \%$ was imported. However, the consumption of milk per capita in Indonesia would continue to be increased since the number remains 11.09 liters per year. The number of milk consumption per capital is below than Asean country, which reaches more than 20 liters per capita per year based on the national milk consumption requirement standard. The large volume of imported milk indicated market prospects in the dairy farm to produce fresh cow's milk as substitute products of dairy imported.

In realizing the livestock development program, Livestock sub-sector started by establishing Livestock Farmer Group (LFG) through a systemic and agribusiness approach. The development of farmer group aims to empower communities to enhance the value, the dignity, enabling and establishing farmer group-independence. According to Mutiawardhana et al. (2013), people empowerments is an effort to improve the value and the dignity of society, in response to the present conditions which possess no escape mechanism from poverty and under development circumstance.

Within the dairy cattle farm, the problem encountered are: recording, the low quality of human resources, the availability of land, and low milk price, which are divided into three sectors. Mukson et al. (2010) stated that some important dairy cattle agribusiness system are: 1) upstream agribusiness system. It is organized on a decentralized basis in the dairy cattle farming activities; 2) on-farm agribusiness system (production activities), and 3) downstream agribusiness subsystem.

The government has sought dairy development through assistance programs (training and counselling, on livestock, and feed) to increase production and productivity of dairy cattle. According to Mukson et al. (2012), other programs which also support the dairy cattle development emphasizing on an increase in livestock productivity, population and ownership of dairy cattle, milk quality, feed quality improvement, human resources improvement, cooperative partnership with Milk Processing Industry (MPI), increase the access of capital and increase milk consumption. Based on this situation, the main issue which needs to be resolved is how the government in collaboration with the MPI dairy cattle can increase the 
income of farmers.

Increasing of farmer income is closely related to the cost of production and business management. The production of dairy cattle is the result combination of various factors used within milk production. Milk production will be optimal if the use of production factors can be allocated efficiently by using production inputs optimally. Haloho et al. (2013), argue that the factors of production such as the cost of forage, the cost of concentrate, capital and farm experience that are less or are not maximized resulting in a low profit of dairy farmers.

Hultgren et al. (2011), explain that the profitability of a dairy business is largely determined by milk revenues and feed costs. There is a clear positive effect on the profitability of cows especially when feeding condition are optimal (Vargas et al. 2002). Korir et al. (2010) report that the dairy sub-sector is one of the most important of the agricultural sub-sectors in Kenya, contributing to $5 \%$ of Kenya's GDP. The estimated annual consumption of milk stands at 3.1 billion liters.

The population of dairy cattle could be increased well if the area possesses a supported potential. Some potential areas that could support the development of dairy cattle are: food securities, human resources, livestock, availability, region demand, the farmer's income and any other supporting facilities and infrastructure, such as lending institutions and local government policy.

Therefore, this study aims to determine influencing factors of farmer group income and analyse dairy farm potential in the West Ungaran District, Semarang Region.

\section{Material and Method}

The sampling area was done intentionally (purposive) in the West Ungaran District, Semarang Regency which was considered as watershed, and the conservation area and the second largest population. The respondents are farmers who keep dairy cattle and they are a member of the farmer group, consist of 13 respondents from "Mardi Mulyo" group, 7 respondents from "Sumber Hasil" group, and 27 respondents from "Ngudi Makmur" group which the total respondents were 47 respondents.

Multiple linear regression was used to analyse influence factors to dairy income. Income dairy farmer (Y) serves as the dependent variable, and the independent variables are the price of milk (X1), the price of concentrate (X2), the price tofu (X3), the number of livestock (X4), the amount of milk production (X5).

The functional relationship between independent variables and the dependent variable that can be written in the mathematical form (Ghozali 2005) as follows:

$\mathrm{Y}=\mathrm{a}+\mathrm{b} 1 \mathrm{X} 1+\mathrm{b} 2 \mathrm{X} 2+\mathrm{b} 3 \mathrm{X} 3+\mathrm{b} 4 \mathrm{X} 4+\mathrm{b} 5 \mathrm{X} 5+\mathrm{e}$

Where :

$\mathrm{X} 1=$ The price of milk (IDR/liter/year)

$\mathrm{X} 2=$ The price of concentrate (IDR/kg/year) 
$\mathrm{X} 3=$ The Price of tofu (IDR/kg/year)

$\mathrm{X} 4=$ The number of livestock (AU)

$\mathrm{X} 5=$ The amount of milk production (liter)

$\mathrm{a}=$ Constanta

$\mathrm{b}=$ Coefisien regresi

$\mathrm{e}=$ Error

SWOT business development of dairy cattle analysis takes into account the internal factor such as strengths and weaknesses variable and external factor such as opportunities and threats. After all the information influencing the continuity of farm development of dairy cattle were collected, the next step is to take advantage of all the information in a qualitative model of strategy formulation.

The model used in this reseach are external and internal matrix SWOT. The afore mentioned models were chosen because it illustrates clearly how the external opportunities and threats facing the farm development of dairy cattle adapted to its strengths and weaknesses (see Figure 1). The parameters used in matrix internal and external, are the internal forces in the development of dairy cattle and external influences facing.

\begin{tabular}{l|c|c}
\hline $\begin{array}{l}\text { Internal Aspects } \\
\frac{1}{\text { External Aspects }}\end{array}$ & $\begin{array}{c}\text { Strengths } \\
(\mathrm{S})\end{array}$ & Weaknesses \\
& & WO \\
\hline Opportunities (O) & SO & WO \\
\hline Threats (S) & ST & WT \\
\hline
\end{tabular}

Figure 1. The SWOT Matrix/Grid.

\section{Results and Discussion}

\subsection{Characteristic of Research Area}

West Ungaran district belongs to the administrative area within Semarang regency, it is located at the northern tip of between $7.57^{\circ}$ to $7.30^{\circ}$ South Latitude and $54.75^{\circ}$ to $39.3^{\circ}$ East Longitude. Based on the geographical position, West Ungaran District is located in the highlands or mountain at 450 meters above sea level, thus the climate is considerably cold withaverage temperatures reaches $22-27^{\circ}$ Celsius. The rainfall average in West Ungaran District is 2,043 $\mathrm{mM}$ per year and generally, rainy months are longer than the dry. Since rain almost every month falls during 2015 - 2016, thus West Ungaran district experience no dry season. 


\subsection{Milk Production}

Dairy cattle productivity is measured by the duration of lactation, lactation peak periods length, dry period length and the amount of milk produced by livestock breeding. Based on Table 1, production of milk during period lactation in the group of "Mardi Mulyo" approximately reaches 47.682 liters/years, the group of "Sumber Hasil" reaches 36.073 liters/year, and the group of "Ngudi Makmur" reaches 120.599 liters/year (Table 1). The average production of milk produced in the group of "Mardi Mulyo" approximately reaches 13.58 liters/day/head, whereas in the group of "Sumber Hasil" milk production arrives at 13.36 liters/day/head, and the group of "Ngudi Makmur" amounts to 9.92 liters of milk production/day/head. The production of milk produced was relatively low.

Table 1. Production of Milk, Number of Lactation Inductions on Dairy Cattle at West Ungaran District

\begin{tabular}{|c|c|c|c|c|}
\hline No. & Description & "Mardi Mulyo" & "Sumber Hasil" & "Ngudi Makmur" \\
\hline 1. & Production milk (L/year) & 47.682 & 36.073 & 120.599 \\
\hline 2. & Price Milk (IDR/L) & 5.000 & 3.143 & 6.000 \\
\hline 3. & Lactation Inductions (Tail) & 13 & 10 & 45 \\
\hline 4. & Consumption of Pedet (L/year) & 5.310 & 9.450 & 13.230 \\
\hline 5. & Sales of Milk (L/year) & 42.372 & 26.623 & 107.369 \\
\hline 6 & Average livestock sales (had) & 2 & 23 & 31 \\
\hline
\end{tabular}

Baga (2013) has reported thatthe total production level of milk in Indonesia is still low. This is highly influenced by the low number of the dairy cow population. This amount is not significant compared to other milk producing countries in developed countries such as in Europe and North America, as well as in some developing countries like India, Brazil, Ukraine, Mexico and Argentina. According to Central Statistical Agency (2012), the total annual national milk production in Ethiopia comes from about 10 million milking cows and is estimated by 3.2 billion liters that are, $1.54 \mathrm{~L} /$ cow on average.

Morey (2011) reported that in 2010, dairy milk production in Central Java reached 106,040 tons up from 70,693 tons in 2005; an average annual increase of ten percent over the last five years. Seventy seven percent of all dairy cow milk production in 2010 in Central Java was from the regencies of Boyolali (42.5 million liters) and Semarang (34.6 million liters). The Indonesian Government has committed resources to support the development of Indonesia's dairy industry with the aim to achieve 50 percent self sufficiency by 2014 .

\subsection{Dairy and Livestock Marketing}

The milk from dairy cattle is generally marketed and distributed directly to the consumer, 
after reducing for 3 months calf consumption. The average sales of milk for each farmer in the group of "Mardi Mulyo", "Sumber Hasil" and "Ngudi Makmur" consecutively arrive at 3,259 liters, 3,803 liters, and 3,977 liters. The price of sold milk of approximately IDR 3,143 to IDR 6,000/liters. The number of cattle sales in each farmer within "Mardi Mulyo", "Sumber Hasil", and "Ngudi Makmur" group were around 2 cattle, 23 cattle, and 31 cattle. The price of sold cattle was ranged between IDR 5,000,000 to IDR 20,000,000. For more details, it can be seen in Table 1.

Livestock breeding farmers who have produced farm products wants their products to be accepted by consumers, farmers had to go through several marketing activities. Farmers marketing activities consist of market information collection, storage, transportation, and sales. Farmers need to understand the marketing patterns. Marketing pattern is a distribution channel of a product from the manufacturer through a limited number of marketing up to the consumer.

\subsection{Dairy Farm Income}

Farmer income is the difference between revenue and variable cost for a year in the maintenance of dairy cattle, to get profit the total income has to be greater than the variable cost incurred in the maintenance of dairy cattle was shown in Table 2.

Table 2. Income of Farmers on Each Group in the West Ungaran District

\begin{tabular}{lrrr}
\hline \multicolumn{1}{c}{ Description } & $\begin{array}{c}\text { LFG of "Mardi } \\
\text { Mulyo" } \\
\text { IDR/year }\end{array}$ & $\begin{array}{c}\text { LFG of "Sumber } \\
\text { Hasil" } \\
\text { IDR/year }\end{array}$ & $\begin{array}{c}\text { LFG of "Ngudi } \\
\text { Makmur" } \\
\text { IDR/year }\end{array}$ \\
\hline 1. Cost Production & 18.396 .000 & 60.736 .000 & 187.200 .000 \\
- Consentrate & 37.084 .030 & 24.090 .000 & 187.610 .000 \\
- Tofu & 56.210 .000 & 0 & 0 \\
- Bran & 1.900 .000 & 1.100 .000 & 1.800 .000 \\
AI & 113.590 .030 & 85.926 .000 & 376.610 .000 \\
Total Cost Production & & & \\
2. Revenue & 148.303 .540 & 153.534 .960 & 637.773 .903 \\
- Milk sales & 75.000 .000 & 113.600 .000 & 273.240 .000 \\
- Livestock sales & 223.303 .540 & 267.134 .960 & 911.013 .903 \\
Total Revenue & 109.713 .510 & 181.208 .960 & 534.403 .903 \\
3. Income (2-1)) & 8.439 .501 & 25.886 .994 & 19.792 .737 \\
- Average (year) & 703.292 & 2.157 .250 & 1.649 .395 \\
- Average (month/had) & & & \\
\hline
\end{tabular}

According to the Table 2, the average farmers income group of "Mardi Mulyo" reaches IDR 703.292/month/had, while group of "Sumber Hasil" reaches IDR 2.157.250/month/had, and group of "Ngudi Makmur" reached IDR 1,649,395/month/had. The income of "Sumber Hasil" and "Ngudi Makmur" group was higher than the result of research conducted by Mukson et al. (2012) reporting that the business profits of dairy in Central Java IDR 819.276/month, while in the group of "Mardi Mulyo" the income was smaller than the both group aforementioned. This situation was due to the animals kept at the peak of the production period, and the different amount of variable. 


\subsection{Factors Influencing Dairy Farmer Income in West Ungaran District}

Based on the results of multiple regression analysis, the function of dairy cattle farm income on each group in the West Ungaran District, Semarang Region can be formulted as follows:

$$
Y=-7425475.502-291.843 X 1-650 X 2-1.675 X 3+1563471.542 X 4+6975.496 X 5+e
$$

Based on the value of R Square of $89.3 \%$, indicated that $89.3 \%$ of the income of dairy cattle in the District Semarang was influenced by the price milk, the price concentrate, the price know dregs, the number of livestock (AU), and the amount of milk, while the value of $11.7 \%$ was influenced by other factors. According to Sudono et al. (2003), dairy cattle business with the sustainability of production was expected to have a ratio $>60 \%$. The results of research conducted by Emawati (2011) and Mukson et al. (2016) showed that the profitability of dairy cattle farmers at Sleman Regency and Semarang District arrive at the average of $41.79 \%$ and $55.61 \%$, respectively.

Based on the research results reported by Mukson et al. (2010), the value of $\mathrm{R}^{2}=0.886$. It indicated that $88.6 \%$ of the variation in the dependent variable can be explained by the independent variable, while only $11.40 \%$ can be explained by other variables. Based on Table 3 calculated $\mathrm{dF}$ value was $68.619(\mathrm{P}=0.01)$. It means that the price of milk, the price concentrate, the price know dregs, the number of livestock ownership, and the amount of milk production significantly influence the income.According to Hadiani \& Susanto (2015), cooperatives take a very important role in the business development of the dairy farmers.

Based on Table 3, the amount of milk production (X5) took a significant effect on income of dairy cattle $(\mathrm{P}<0.05)$. Milk production took a significant effect on the income earned the moment the production of milk produced by the farmers was higher, the revenue obtained will increase. Every $1 \%$ increasing in milk production would increase income earned. The prices of milk (X1), concentrate (X2), know dregs (X3), and livestock owners in livestock units $(\mathrm{X} 4)$ possess no significant effect on the operating income of dairy cattle $(\mathrm{P}=0.05)$. This is due to the prices of milk which arrive at a negative regression coefficient value of -291.843 , the concentrate of -650 , know dregs of -1.675 , meaning that every third increase of the price of one percent will decrease the revenue of the coefficient value.

Table 3. Factors Influencing Dairy Cattle Income in the West Ungaran District

\begin{tabular}{lrc}
\hline \multicolumn{1}{c}{ Variable } & Regression Coefficient & Significant Value \\
\hline Constanta (a) & -7425475.502 & .392 \\
The price of milk (X1) & -291.843 & .862 \\
The price concentrate (X2) & -.650 & .263 \\
The price know dregs (X3) & -1.675 & .093 \\
Livestock Ownership (X4) & 1563471.542 & .124 \\
Milk Production (X5) & 6975.496 & .000 \\
\hline F Sign & & 68.619 \\
\hline R Square $\left(\mathrm{R}^{2}\right)$ & & 0.893 \\
\hline
\end{tabular}

As for the ownership of livestock and milk production it takes a positive coefficient of 1563471.542 and 6975.496 which means that by increasing the price of one per cent of the two inputs will increase the income of farmers by the coefficient value. In improving the 
productivity of dairy cattle in West Ungaran District, the efforts that are requered to be made by the farmers are by increasing the quantity and quality of feed concentrates and pulp to subsequently increase the production of milk. Additionally, the farmer should pay an attention to changes in input prices, due to rising input prices will lead to increased operational costs thus the farmer's income will be reduced. As well as breeder must consider the amount of feeding, because it will reduce wasteful expenditure made.

\subsection{SWOT Analysis}

SWOT analysis could be employed to apprehend how substantial the potential development of the dairy cattle farm in West Ungaran District by identifying common conditions that exist in West Ungaran District. According to Rangkuti (2006), the SWOT analysis is a strategy planning method used to evaluate the strengths, weaknesses, opportunities and threats to the business. After attaining all the information that influence the potential development of the dairy farm, the next step is to utilize all this information through the internal external matrix. Based on the Table 4 and 5, it was obtained an amount score of 3.61 of internal factors and external factors arrives at the amount score of 2.73. Then the Figure 2 included in the external internal matrix on the region IV (stability strategy which is the strategy set without changing the strategy direction that has been set).

Table 4. Matrix Internal Factor Evaluation (IFE)

\begin{tabular}{|c|c|c|c|}
\hline Internal Factor & Value & Rating & Score \\
\hline \multicolumn{4}{|l|}{ A. Strengths } \\
\hline 1. Carrying capacity of land & 0.1 & 4 & 0.4 \\
\hline 2. The climate and natural conditions & 0.08 & 3 & 0.24 \\
\hline 3. The population of dairy cows & 0.1 & 4 & 0.4 \\
\hline 4. Raising Experience & 0.08 & 3 & 0.24 \\
\hline 5. The current market access & 0.1 & 4 & 0.4 \\
\hline Sub Total of Strengths & 0.46 & 18 & 1.68 \\
\hline \multicolumn{4}{|l|}{ B. Weaknesses } \\
\hline 1. Lack of knowledge and skills & 0.1 & 4 & 0.4 \\
\hline 2. Facilities and infrastructure is limited & 0.1 & 4 & 0.4 \\
\hline 3. Limitations of venture capital & 0.1 & 4 & 0.4 \\
\hline 4. Raising as a sideline business & 0.1 & 4 & 0.4 \\
\hline 5. Adoption of low technology & 0.08 & 3 & 0.33 \\
\hline Sub Total Weaknesses & 0.48 & 19 & 1.93 \\
\hline Total Internal Factors & 1.00 & 37 & 3.61 \\
\hline
\end{tabular}


Table 5. Matrix External Factor Evaluation (EFE)

\begin{tabular}{|c|c|c|c|}
\hline External Factor & Value & Rating & Score \\
\hline \multicolumn{4}{|l|}{ A. Opportunities } \\
\hline 1. The development center of dairy cattle & 0.07 & 2 & 0.14 \\
\hline 2. Government support & 0.11 & 3 & 0.33 \\
\hline 3. The extent of market opportunities & 0.11 & 3 & 0.33 \\
\hline 4. Utilization of the natural resources is not maximized & 0.11 & 3 & 0.33 \\
\hline 5. Increasing the price of meat and milk & 0.07 & 2 & 0.14 \\
\hline Sub Total of Opportunities & 0.47 & 13 & 1.27 \\
\hline \multicolumn{4}{|l|}{ B. Threats } \\
\hline 1. Lack of public trust in government & 0.11 & 3 & 0.33 \\
\hline 2. Limited personnel training facility extension & 0.11 & 3 & 0.33 \\
\hline 3. The population is increasing & 0.11 & 3 & 0.33 \\
\hline 4. The livestock disease & 0.07 & 2 & 0.14 \\
\hline \multirow{3}{*}{$\begin{array}{c}\text { Sub Total of Treats } \\
\text { Total External Factor }\end{array}$} & 0.11 & 3 & 0.33 \\
\hline & 0.51 & 14 & 1.46 \\
\hline & 1.00 & 27 & 2.73 \\
\hline
\end{tabular}

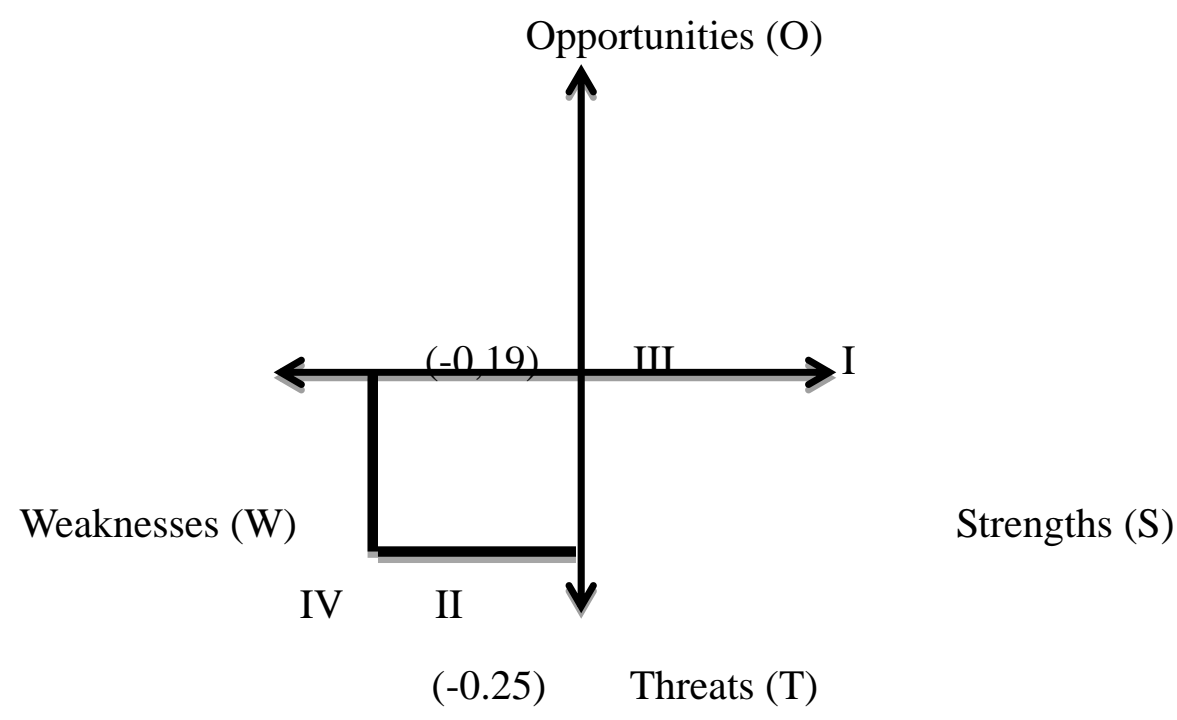

Figure 2. SWOT Analysis Diagram of Development Business Dairy Cow on 3 Livestock Farmer Groups in the West Ungaran District

According to Morey (2011), this report focuses specifically on a SWOT analysis for Central Java's dairy farming industry that it should be read in conjunction with the main report containing the Indonesian national SWOT analysis because many of the challenges that face the Indonesian dairy farming industry on a national basis also exist within the Central Java region. The report discloses that cooperatives and dairy farmers have been abandoning their membership in Central Java because (1) some cooperatives and farmers have become discouraged with GKSI's past management team and its efforts to develop the dairy farming 
industry in Central Java, and (2) some cooperatives and members have found that they able to obtain better returns for their milk from direct sales agreements with milk processors and cooperatives that are not members of GKSI.

A review was undertaken of the most recently available annual reports and financial statements of the major cooperatives in Central Java and found that many cooperatives have a balance sheet that contains: (1) a large sums of money due from the cooperative's members; and (2) alarge sums of money due to the cooperative's bankers and other credit providers. It was recommended that the Ministry of Agriculture review financial management practices. In conclusion, there is very clear evidence that a free market is working in Central Java as businesses, cooperatives, and individual farmers are making strategic decisions on (1) what products they produce to maximize their incomes and (2) where they sell their products to maximize their incomes.

\section{Conclusions}

- Milk production significantly influences the income of dairy farmers.

- Farmers income in "Mardi Mulyo", "Sumber Hasil" and "Ngudi Makmur" group in a row during one month arrived at IDR 703,292/had, IDR 2.157.250/had and IDR 1,649,395/had, respectively.

- Based on the results of business development analysis of dairy cattle in West Ungaran District, it could be concluded that the dairy farm in category IV, stability strategy and coordinate points are in quadrant IV.

\section{References}

Baga, L. M. (2013). Co-operative Entrepreneurs and Agribusiness Development. A Study Towards the Development of Agribusiness Co-operatives in Indonesia. Philips-University Marburg. 286 p.

Central Statistical Agency. (2012). Ethiopia sample survey enumeration. Addis Ababa Ethiopia.

Directorate General of Animal Husbandry and Health. (2012). Livestock Statistics and Animal Health 2011. Agriculture Ministry of the Republic of Indonesia, Jakarta.

Directorate General of Animal Husbandry. (2006). Livestock Statistics 2006. Directorate General of Livestock, Agriculture Ministry of the Republic of Indonesia, Jakarta.

Emawati, S. (2011). Profitability of Community Dairy Farming in Sleman Regency. Animal Husbandry Science, 9(2), 100-108.

Firman, A. (2010). Dairy Cows Agribusiness from Upstream to Downstream. Publisher Widya Padjadjaran, Bandung.

Francesconi, G. N., Heerink, N., \& D’Haese, M. (2010). Evolution and Challenges of Dairy Supply Chains: Evidence from supermarkets, industries and consumers in Ethiopia. Food Policy, 35(1), 60-68. https://doi.org/10.1016/j.foodpol.2009.06.003 
Ghozali. (2005). Applications Multivariate Analysis with SPSS Program. Diponegoro University Publisher, Semarang.

Hadiana, D. P. P., \& Susanto, W. E. (2015). Dairy cattle business development through agribusiness system supporting business district of Karangploso Ngijo in the village of Malang regency. p. 221-225. In Proc. Inter. Seminar Improving Tropical Animal production for Food Security, 3-5 November 2015. Faculty of Animal Science Universitas Halu Oleo, Kendari, Southeast Sulawesi, Indonesia. Unhalu Press.

Haloho, R. D., Santoso, S. I., Marzuki, S., Roessali, W., \& Setiadi, A. (2013). Profit Function Analysis of Dairy Cattle Farming in Getasan and West Ungaran Districts, Semarang Regency. J. Indonesian Trop. Anim. Agric. 38(2), 116-122. https://doi.org/10.14710/jitaa.38.2.116-122

Headey, D., Taffesse, A. S., \& You, L. (2014). Diversification and development in pastoralist Ethiopia. World Dev. 56, 200-213. https://doi.org/10.1016/j.worlddev.2013.10.015

Hultgren, J., Svensson, C., \& Pehrsson, M. (2011). Rearing Conditions and Lifetime Milk Revenues in Swedish Dairy Cows. J. Livest. Sci., 137, 108-115.

https://doi.org/10.1016/j.livsci.2010.10.005

Korir, M. K., Kibet, J., Kipsat, M. J., Nyangweso, P. M., \& Rirei, M. (2010). Dairy cattle productivity after the post-election crisis in Uasin Gishu District of Kenya. Contributed Paper Presented at the Joint $3^{\text {rd }}$ African Association of Agricultural Economists (AAAE) and $48^{\text {th }}$ Agricultural Economists Association of South Africa (AEASA) Conference, Cape Town, South Africa, September 19-23, 2010. 12 p.

Morey, P. (2011). Dairy industry development in Indonesia. Final Report, May 2011. International Finance Corporation, Word Bank Group. 57 p.

Mukson, E. T., Handayani, M., \& Gayatri, S. (2010). The Potency of Dairy Cattle Agribusiness Development in Semarang Regency, Central Java. J. Indonesian Trop. Anim. Agric. 35(3), 179-184. https://doi.org/10.14710/jitaa.35.3.179-184

Mukson, I. S., Sudjadmogo, S. I., \& Setiadi, A. (2012). Analysis of Various Factors in Order to Enhance Productivity and Income of Dairy Cattle Farmers in Central Java Indonesia. J. Indonesian Trop. Anim. Agric., 37(3), 220-228. https://doi.org/10.14710/jitaa.37.3.220-228

Mukson, S. S. I., Nina, H. I., Setiyawan, H., \& Handayani, M. (2016). Analysis of the Profitability of Dairy Farmers Based on the Scale of Livestock Ownership in District Semarang. In S.Y. Rusina, A. Fachruddin, R. Azis \& D. Rosalia (Eds). Proc. Inter. Conference Agribusiness Development for Human Welfare. Small and Medium-sized Enterprises Competitiveness (pp.216-220). Department of Agribusiness, Faculty of Agriculture, University Muhammadiyah Malang.

Mutiawardhana, R., Emawati, S., \& Handayanta, E. (2013). Livestock-Based Community Empowerment Model in the Dry Land Farming Area of Kemejing Village, Semin Sub-District, Gunung Kidul District. Tropical Animal Husbandry, 2(1), 41-50.

Rangkuti, F. (2006). SWOT Analysis technique for dissecting business cases. Publisher PT. 
Gramedia Main Library, Jakarta.

Sudono, A., Rosdiana, F. R., \& Setiawan, B. (2003). Intensive breeding of dairy cows. Publisher Agro Media Library, Jakarta.

Vargas, B., Groen, A. F., Herrero, M., \& Arendonk, J. A. M. V. (2002). Economic Values for Production and Functional Traits in Holstein Cattle of Costa Rica. Lives. Prod. Sci., 75, 101-116. https://doi.org/10.1016/S0301-6226(01)00305-0

\section{Copyright Disclaimer}

Copyright for this article is retained by the author(s), with first publication rights granted to the journal.

This is an open-access article distributed under the terms and conditions of the Creative Commons Attribution license (http://creativecommons.org/licenses/by/4.0/). 